\title{
Creating Healthier Salad Dressings at Home ${ }^{1}$
}

\author{
L. Johnson, J. Breslawski, M. Arick, K. Zamojski, and A. Simonne ${ }^{2}$
}

This publication is part of a series to complement A Healthy Table Virtual Cooking School. The purpose of the cooking school is to educate the general public on healthy home meal preparation practices.

Research suggests there are many health benefits to preparing meals at home. Home food preparation can foster a more nutritious diet. For example, homemade salad dressing allows the use of healthier recipes that can include more wholesome ingredients lower in saturated fats, sodium, and sugar, making a more nutrient-dense product. Measuring ingredients correctly produces a desirable food product and allows more accurate calculation of calories and nutrients. This can help consumers maintain a balanced dietary intake.

A salad dressing is made up of three parts: a fat, an acid, and seasonings. Examples are listed in the chart below.

\begin{tabular}{|l|l|l|}
\hline \multicolumn{1}{|c|}{ Fat } & \multicolumn{1}{c|}{ Acid } & \multicolumn{1}{c|}{ Seasonings } \\
\hline Oil & Lemon juice & Parsley \\
\hline Yogurt & Lime juice & Oregano \\
\hline Sour cream & Orange juice & Paprika \\
\hline Mayonnaise & Vinegar (any type) & Celery seed \\
\hline & & Garlic \\
\hline & & Onion \\
\hline & & Mustard \\
\hline
\end{tabular}

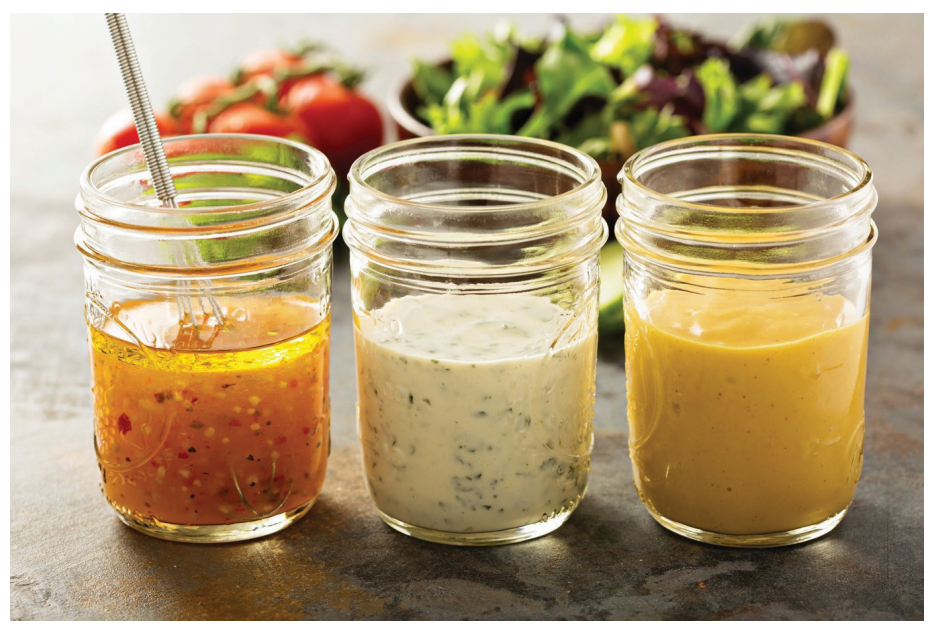

Figure 1. Variety of homemade sauces and salad dressings in mason jars including vinaigrette, ranch and honey mustard. Credits: iStock/Getty Images Plus/VesekivaEkeba

Fresh homemade dressings can be prepared quickly before a meal. Depending on the equipment available in your kitchen, salad dressings can be made using a mixing bowl, a jar with a tightly fitted lid, or a blender or food processor. Start by measuring your ingredients into the appropriate container. Since homemade salad dressing is made without any preservative, it should be consumed within a day or two.

1. Mixing bowl: Combine the ingredients (except for the fat) in the bowl. Pour in the fat slowly while whisking to combine ingredients.

1. This document is FCS3363, one of a series of the Department of Family, Youth and Community Sciences, UF/IFAS Extension. Original publication date December 2021. Visit the EDIS website at https://edis.ifas.ufl.edu for the currently supported version of this publication.

2. L. Johnson, Extension agent, family and consumer sciences, UF/IFAS Extension Lake County; J. Breslawski, Extension agent, family and consumer sciences, UF/IFAS Extension Okaloosa County and UF/IFAS Extension Walton County; M. Arick, Extension director, 4-H agent, UF/IFAS Extension Liberty County, and family and consumer sciences agent, UF/IFAS Extension Liberty County and UF/IFAS Extension Calhoun County; K. Zamojski, regional specialized agent, family and consumer sciences, UF/IFAS Extension Northwest District; and A. Simonne, professor, Department of Family, Youth and Community Sciences; UF/IFAS Extension, Gainesville, FL 32611.

The Institute of Food and Agricultural Sciences (IFAS) is an Equal Opportunity Institution authorized to provide research, educational information and other services

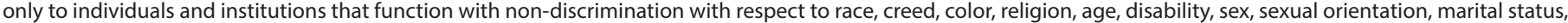

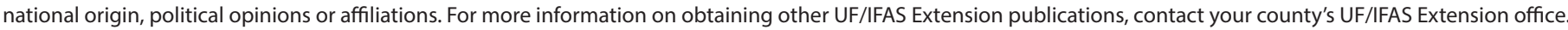
U.S. Department of Agriculture, UF/IFAS Extension Service, University of Florida, IFAS, Florida A \& M University Cooperative Extension Program, and Boards of County Commissioners Cooperating. Andra Johnson, dean for UF/IFAS Extension. 
2. Jar with a tight lid: Place the ingredients in the jar, replace the lid until it fits tightly, and shake well until all ingredients are combined.

3. Blender or food processor: Place all items in the appliance and blend to the desired consistency. The blender or food processor method is especially effective to combine thicker or solid ingredients, such as avocado for the avocado salad dressing recipe below.

Consider using homemade dressings to flavor foods beyond your typical salads. Creamy dressings can be used as dips with colorful fresh or blanched vegetables or added as a spread to burgers or sandwiches. Vinaigrette dressings make delicious marinades for poultry, meat, fish, and vegetables. For example, a honey mustard dressing can be brushed on chicken or salmon or tossed with vegetables before roasting them. A creamy avocado dressing can be used to top fish tacos, spread in a wrap, or placed on top of a fillet of fish, meat, or poultry.

\section{Homemade Salad Dressing}

\section{Recipes}

\section{Creamy Avocado}

1 ripe avocado, peeled

$1 / 4$ cup plain Greek yogurt

2 tablespoons olive oil

2 tablespoons lemon juice

1 teaspoon Dijon mustard

Salt and pepper to taste

${ }^{\star}$ Add water to adjust to desired consistency.

Recipe source: Academy of Nutrition and Dietetics

\section{Honey Mustard}

$1 / 4$ cup honey

$1 / 4$ cup Dijon mustard

$1 / 4$ cup plain Greek yogurt

$1 / 8$ teaspoon salt

Pepper to taste

Recipe source: Eat Right Essentials: Cooking Basics, Academy of Nutrition and Dietetics, pp. 23-24

\section{Citrus Vinaigrette}

$1 / 2$ cup orange juice

6 tablespoons red wine vinegar

4 teaspoons honey

3 teaspoons Dijon mustard

2 tablespoons olive oil

Recipe source: https://www.tasteofhome.com/recipes/

citrus-vinaigrette/

\section{Balsamic Vinaigrette}

1 garlic clove, minced

$1 / 2$ teaspoon thyme

1 teaspoon basil

1 tablespoon dry mustard

$1 \frac{1}{2}$ tablespoon honey

$1 / 4$ cup balsamic vinegar

$1 / 4$ cup olive oil

Salt and pepper to taste

Recipe adapted from: https://weolive.com/blog/eat-drink/ simple-salad-dressing-recipes/

\section{Resources}

Academy of Nutrition and Dietetics. (2020). Eatright Essentials: Cooking Basics (pp. 23-24). Academy of Nutrition and Dietetics. https://www.eatrightstore.org/product-type/ brochures-handouts/cooking-basics

Mills, S., White, M., Brown, H., Wrieden, W., Kwasnicka, D., Halligan, J., Robalino, S., \& Adams, J. (2017). Health and Social Determinants and Outcomes of Home Cooking: A Systematic Review of Observational Studies. Appetite, 111, 116-134. https://www.sciencedirect.com/science/article/pii/ S0195666316309576

Tiwari, A., Aggarwal, A., Tang, W., \& Drewnowski, A. (2017). Cooking at Home: A Strategy to Comply With U.S. Dietary Guidelines at No Extra Cost. American Journal of Preventive Medicine, 52(5), 616-624. https://www.sciencedirect.com/science/ article/pii/S0749379717300235?casa_token=9YWtpmq2ooAAAAA:fqy1NuW45UCcTVK50y-5j6AfW33kB9Y_ RZXVpUTlHd0BstxCdidp48Nsuzfkh-wH0Iby9bA7DXQ 